\title{
Making the Switch: Reflections on Integrating Community Service Learning into a First Year Design Project Course
}

\author{
Brian Frank \\ Department of Electrical and Computer Engineering, Queen's University \\ brian.frank@queensu.ca
}

\begin{abstract}
This paper presents the objectives, technique, and student feedback after introducing community service projects into a first year design course in the engineering program at Queen's University. An overview of the state of community service learning (CSL) in Canada is presented. Results from a postcourse survey are used to compare student perceptions of CSL projects with more traditional projects. Responses from the survey indicate that a greater proportion of students on CSL projects felt their projects required creativity to solve.
\end{abstract}

\section{Introduction}

There has been much discussion about professional skills in engineering curricula, particularly in first year. Open-ended design projects are commonly used in engineering, as well as other disciplines, to help foster design skills, communication skills, and teamwork, and expose students to "real-world" activities in an educational setting. These kinds of projects have been shown to improve student recruitment and retention, particularly in underrepresented groups [1]. Good open-ended projects are not only challenging, but also motivating, and designing projects that students want to complete can be a challenge. One method of creating a motivating project is to create one in which the students tackle a real problem, whether in the local community, or larger community. In this way, student time and skills are used for a purpose and students see the value in their work. This is commonly known as community service learning (CSL).

This paper will survey the state of CSL in some Canadian engineering programs, present an overview of its use in our program, and present outcomes from surveys.

\section{Engineering skill development}

All first year students entering the Faculty of Applied Science at Queen's University, numbering around 560 on average, enrol in a full year course called APSC100, Practical Engineering Modules [2]. It was developed in 1997 to provide an opportunity for students to develop basic engineering skills, primarily through experiential learning. It has two primary modules: Module 2 emphasizes measurement, analysis and design of experiments [3]. Module 3 is a semesterlong open ended design project that focuses on developing five critical skills:

- engineering design
- technical communications
- information literacy
- project management
- team skills

Four complementary professional skill workshops are offered throughout the semester. Half of the first year students complete Module 2 in the fall semester, while the other half enrol in Module 3; in the winter semester they switch. This split allows both modules to handle approximately 280 students at a time, rather than the full 560 .

Design teams of 3-5 first year students are managed by an upper year engineering student who meets with the students regularly to guides the project, and serve as a mentor to the first-year students. These upper year project managers are critical to the success of the projects, and competition for these positions is tough. Each project is also guided by an engineering faculty member. This module has a core staff of one faculty member and one administrative assistant.

At the beginning of the semester, students are asked to indicate their top ten project preferences from a list of approximately 30 projects, and are then formed into groups based on timetable and project preference.

The team projects are provide the content for workshops on professional skills. These workshops are as follows: 
1. Engineering Design: The first workshop is run immediately after student teams are formed. This session serves as an ice-breaker for the teams, and introduces the design process in the context of a 1hour design-and-build challenge.

2. Information literacy: The Engineering and Science Library runs this workshop on information research for engineers, and has created a complementary web portal. Students teams learn about finding, evaluating, and citing information in the context of their project.

3. Technical communication: Staff from the Engineering Communications Program (ECP) meet with students teams after they have created the first draft of their project report, and highlight important factors in engineering writing. The ECP is integrated into seven engineering courses offered in multiple years in most engineering programs.

4. Teamwork: At the end of the project, student teams meet with Personality Dimensions instructors to discuss team issues, and to learn more about their own personality styles, and team strengths.

Traditionally all students in the course worked on projects proposed by engineering faculty. Some of these involved some deliverable to a client, but the majority were simply designed by faculty to provide an activity for students. In the past two years an initiative was put in place to develop learning experiences for students using projects proposed by community organizations, including local non-profit agencies and on-campus groups. Such CSL projects have been shown to not only improve recruitment and retention of under-represented groups, but also to motivate students, and to instill a sense of connection with the local community. These projects also provide the opportunity for students to learn to interact with non-technical people, and to fulfil an otherwise unmet need.

\section{Background: Community Service Learning}

In the United States, service learning is defined by the National and Community Service Trust Act of 2000 as follows [4]:

... a method under which students or participants learn and develop through active participation in thoughtfully organized service that is conducted in and meets the needs of a community; is coordinated with an elementary school, secondary school, institution of higher education, or community service program, and with the community; and helps foster civic responsibility; and that is integrated into and enhances the academic curriculum of the students, or the educational components of the community service program in which the participants are enrolled; and provides structured time for the students or participants to reflect on the service experience.

The Canadian Association for Community ServiceLearning defines service learning as "an educational approach that integrates service in the community with intentional learning activities " [5].

In addition to providing motivation, CSL has the benefit of fulfilling an unfilled need in the community. Service learning has been found to have a positive effect on interpersonal development, ability to work well with others, leadership and communication skills, applying learning to real world, academic learning, and university relations in the community. Much of this is documented in a comprehensive review of community service learning (CSL) surveys from 19932000, which assesses personal outcomes, social outcomes, learning outcomes, and career development resulting from CSL [6].

The Accreditation Board of Engineering and Technology (ABET) established criteria for engineering programs in the United States, commonly known as ABET 2000, that requires engineering students to develop the ability to function on multidisciplinary teams, communicate, and appreciate the impact of engineering. Similar recommendations were made by the National Academy of Engineering [7]. Community service learning has been seen as a suitable technique for developing these skills, and is being now commonly implemented in engineering programs in the U.S.A.

In 1995 Purdue University formed Engineering Projects in Community Service (EPICS) to administer their community service projects. It includes member universities across the United States, as well as one in New Zealand. Projects run by EPICS member universities generally have three attributes in common: they are multidisciplinary, vertically integrated (i.e. involve students at various stages in their undergraduate degree), and long term (run for multiple terms, possibly with different teams of students). Its projects include students from a variety of disciplines. Student participation of underrepresented groups is higher in EPICS courses than in general engineering, and students report that it played a role in their resolve to stay in engineering [8].

Community service learning, under various names, has been used in Canadian institutions on a small scale for many years, but at the institutional level developed later than in the U.S. In 2004 a grant from J.W. McConnell Family Foundation was used to form the Canadian Association for Community Service- 
Learning (CACSL) to support service-learning programs across Canada. They have served as a resource centre for service learning initiatives in Canada.

In their 2006 study the CACSL concluded that CSL is still emerging in Canada, and that "there is important groundwork to be done to educate faculty, student affairs professionals, and community agencies on what CSL is, the roles of each partner, as well as the goals and outcomes of CSL for the student, institution, and community. " [5]

CSL is becoming a mainstream educational technique in Canada. The CACSL lists over 20 Canadian higher education institutions offering some form of CSL in their programs, both curricular and co-curricular [9]. CSL has begun to make inroads in the engineering education community. A variety of Canadian universities incorporate international development projects into engineering case studies and design challenges, including University of Calgary, McMaster University, University of Laval, University of New Brunswick, and University of Western Ontario [10]. The University of Toronto offers Engineering Strategies \& Practise (ESP) [11,12], which is a firstyear program that uses engineering design projects to develop information literacy, design, and project management skills. They have worked with a variety of community groups on CSL projects [13].

\section{Engineering CSL pilot projects}

In 2005-2006 approximately three dozen first year engineering students at Queen's University were part of a new initiative to partner engineering students with community groups. Three projects were designed in collaboration with two community agencies: Habitat for Humanity, a non-profit housing agency, and Thousand Islands Elementary School, located half an hour northeast of Kingston.

In the 2006-2007 academic year the initiative was expanded to include more off-campus non-profit community groups and on-campus agencies. The partner agencies and projects from this year are listed in Table 1. Several of the projects were divided into sub-projects, and undertaken by multiple student teams. In all, approximately half of the 560 students were involved in a CSL project.
Table 1. Summary of agency projects in 20062007

\begin{tabular}{|c|c|}
\hline Partner & Project \\
\hline $\begin{array}{l}\text { Habitat for } \\
\text { Humanity }\end{array}$ & $\begin{array}{l}\text { Alternate Uses for } \mid \text { Building } \\
\text { Materials }\end{array}$ \\
\hline $\begin{array}{l}\text { Habitat for } \\
\text { Humanity }\end{array}$ & $\begin{array}{l}\text { Design and Construction of a } \\
\text { Can-Crusher }\end{array}$ \\
\hline $\begin{array}{l}\text { Thousand Islands } \\
\text { Elementary } \\
\text { School }\end{array}$ & $\begin{array}{l}\text { Engineering Design Challenges: } \\
\text { Heat }\end{array}$ \\
\hline $\begin{array}{l}\text { Thousand Islands } \\
\text { Elementary } \\
\text { School }\end{array}$ & $\begin{array}{l}\text { Engineering Design Challenges: } \\
\text { Water Systems }\end{array}$ \\
\hline $\begin{array}{l}\text { Limestone } \\
\text { District School } \\
\text { Board }\end{array}$ & Physics Outreach \\
\hline $\begin{array}{l}\text { Queen's Project } \\
\text { on International } \\
\text { Development } \\
\text { (QPID) }\end{array}$ & $\begin{array}{l}\text { Design of a water distribution } \\
\text { system for a community in } \\
\text { Guyana }\end{array}$ \\
\hline $\begin{array}{l}\text { Kingston } \\
\text { Environmental } \\
\text { Advisory Forum } \\
\text { (KEAF) } \\
\end{array}$ & $\begin{array}{l}\text { Siting and Design of a Multi- } \\
\text { Purpose Trail for the Kingston } \\
\text { Inner Harbour: The Causeway to } \\
\text { the Woolen Mills }\end{array}$ \\
\hline $\begin{array}{l}\text { St. Mary's of the } \\
\text { Lake Hospital }\end{array}$ & Wheelchair Seat Lift Design \\
\hline $\begin{array}{l}\text { St. Mary's of the } \\
\text { Lake Hospital }\end{array}$ & $\begin{array}{l}\text { Assessment of accessible } \\
\text { swimming pool designs }\end{array}$ \\
\hline $\begin{array}{l}\text { St. Mary's of the } \\
\text { Lake Hospital }\end{array}$ & Automobile entry device \\
\hline $\begin{array}{l}\text { Living Energy } \\
\text { Laboratory }\end{array}$ & Energy Consumption \\
\hline $\begin{array}{l}\text { Living Energy } \\
\text { Laboratory }\end{array}$ & Residential Wind Funnel \\
\hline $\begin{array}{l}\text { Living Energy } \\
\text { Laboratory }\end{array}$ & Residential Solar Panels \\
\hline $\begin{array}{l}\text { Living Energy } \\
\text { Laboratory }\end{array}$ & Heat Transfer Through Plastic \\
\hline $\begin{array}{l}\text { Integrated } \\
\text { Learning Centre }\end{array}$ & Green Wall Assessment \\
\hline $\begin{array}{l}\text { Integrated } \\
\text { Learning Centre }\end{array}$ & $\begin{array}{l}\text { HVAC Enthalpy Wheel } \\
\text { Assessment }\end{array}$ \\
\hline $\begin{array}{l}\text { Integrated } \\
\text { Learning Centre }\end{array}$ & $\begin{array}{l}\text { Power consumption across } \\
\text { campus }\end{array}$ \\
\hline
\end{tabular}

\section{Student feedback}

At the end of each semester in 2006-2007, students completing the design projects were asked to complete a voluntary web survey. The survey asked students to respond to a series of questions on a Likert scale 
(5=strongly agree $/ 4=$ agree $/ 3=$ neither agree nor disagree $/ 2=$ disagree $/ 1=$ strongly disagree), and to provide general feedback in a free-text box. The questions asked to all students are listed in Table 2; an additional 4 questions were asked of students on CSL projects only.

The web survey asked students to identify themselves as being part of an agency (CSL) project, or a traditional project (in the course CSL projects were labelled "agency projects", and that was how they were identified on the survey). The responses of students on the agency projects were compared to those on the traditional projects. Of the approximately 560 students in the course in 2006-2007, 180 responded to the survey.

The means of the responses to 11 of the questions are listed in Figures 1 and 2. Using a Mann-Whitney $U$ test, four questions were identified as having statistically significant differences (using a 95\% confidence interval) between CSL and traditionalproject respondents. Details are shown below in Table 3.

Table 3. Questions on student survey with statistically significant differences between CSL projects and traditional

\begin{tabular}{|c|c|c|}
\hline \multirow[t]{2}{*}{ Question } & \multicolumn{2}{|c|}{$\begin{array}{l}\% \text { agree or strongly } \\
\text { agree }\end{array}$} \\
\hline & CSL & Traditional \\
\hline $\begin{array}{l}\text { The project encouraged our } \\
\text { group to be creative: }\end{array}$ & 68 & 44 \\
\hline $\begin{array}{l}\text { Ifeel more comfortable } \\
\text { doing oral presentations } \\
\text { now than at the beginning of } \\
\text { the semester }\end{array}$ & 56 & 37 \\
\hline $\begin{array}{l}\text { The engineering } \\
\text { communications tutors were } \\
\text { helpful }\end{array}$ & 50 & 32 \\
\hline $\begin{array}{l}\text { Our team's Project } \\
\text { Manager was a valuable } \\
\text { source of guidance, } \\
\text { information, and resources. }\end{array}$ & 65 & 81 \\
\hline
\end{tabular}

Table 2. Questions on the student survey

\begin{tabular}{|c|c|}
\hline \# & Question \\
\hline 1 & My project was interesting \\
\hline 2 & I found the project too difficult. \\
\hline 3 & $\begin{array}{l}\text { The project encouraged our group to be } \\
\text { creative. }\end{array}$ \\
\hline 4 & $\begin{array}{l}\text { This course changed my perceptions about the } \\
\text { skills needed by engineers. }\end{array}$ \\
\hline 5 & $\begin{array}{l}\text { We were given the necessary instruction about } \\
\text { safety in our lab/workspace. }\end{array}$ \\
\hline 6 & $\begin{array}{l}\text { Our team's Project Manager was a valuable } \\
\text { source of guidance, information, and resources. }\end{array}$ \\
\hline 7 & $\begin{array}{l}\text { I found that it was important to work as a team } \\
\text { to complete this project. }\end{array}$ \\
\hline 8 & $\begin{array}{l}\text { Our team's Faculty Sponsor was a valuable } \\
\text { resource. }\end{array}$ \\
\hline 9 & $\begin{array}{l}\text { My Project Manager showed genuine concern } \\
\text { and interest in the team members. }\end{array}$ \\
\hline 10 & $\begin{array}{l}\text { Our team would have benefited from more } \\
\text { contact with the Faculty Sponsor. }\end{array}$ \\
\hline 11 & $\begin{array}{l}\text { I feel more comfortable doing oral } \\
\text { presentations now than at the beginning of the } \\
\text { semester. }\end{array}$ \\
\hline 12 & I did not learn much during the design project. \\
\hline 13 & $\begin{array}{l}\text { The engineering communications tutors were } \\
\text { helpful. }\end{array}$ \\
\hline 14 & $\begin{array}{l}\text { The library information sessions helped me } \\
\text { learn how to find information. }\end{array}$ \\
\hline 15 & $\begin{array}{l}\text { The Personality Dimensions session was } \\
\text { useful. }\end{array}$ \\
\hline 16 & $\begin{array}{l}\text { This project helped me feel more comfortable } \\
\text { working in a team. }\end{array}$ \\
\hline 17 & $\begin{array}{l}\text { I learnt a lot about creating engineering } \\
\text { documents in this course. }\end{array}$ \\
\hline 18 & Overall I rate my team's Project Manager as: \\
\hline 19 & $\begin{array}{l}\text { Overall I rate the design project and my } \\
\text { experience as: }\end{array}$ \\
\hline
\end{tabular}




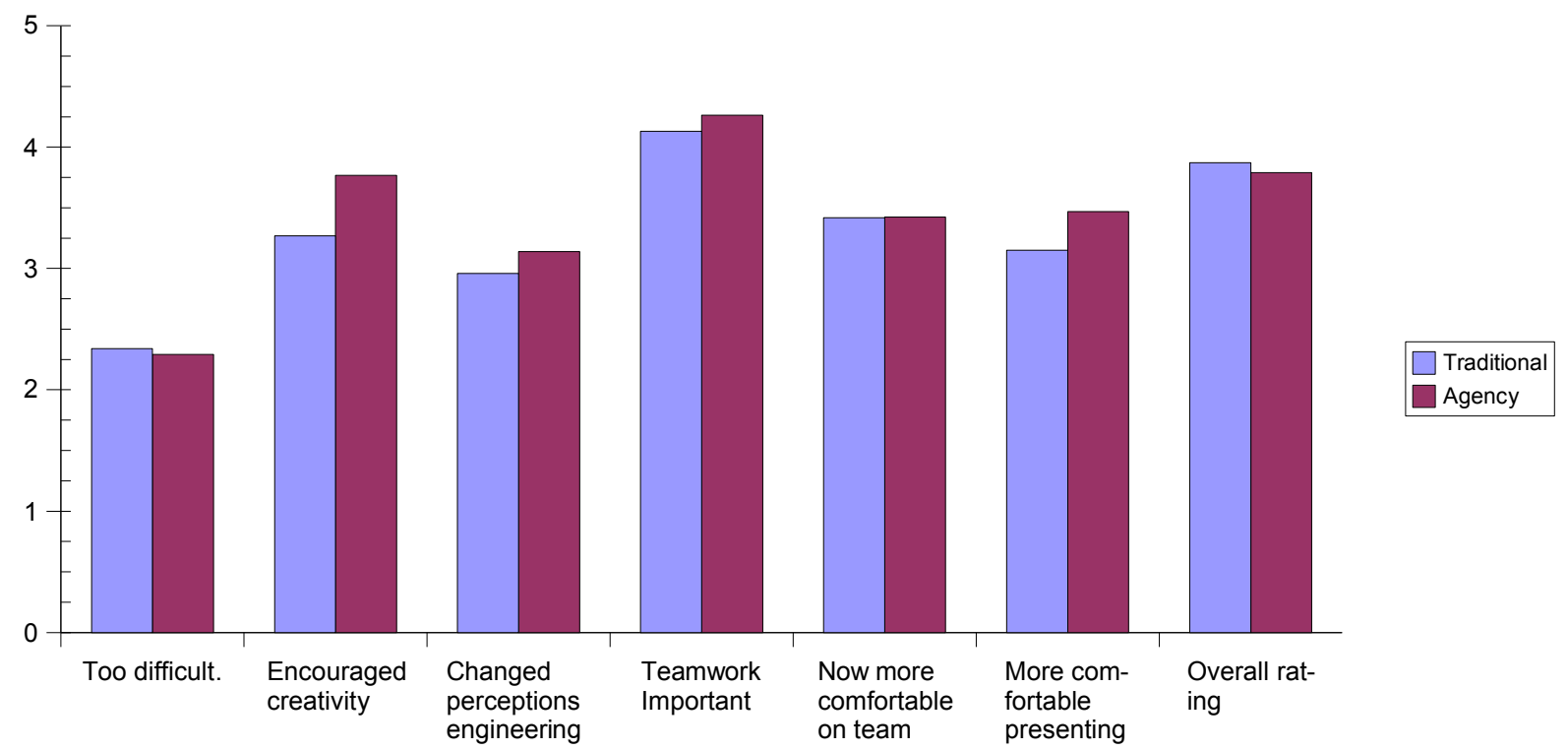

Figure 1: Average student survey responses to questions regarding project overall

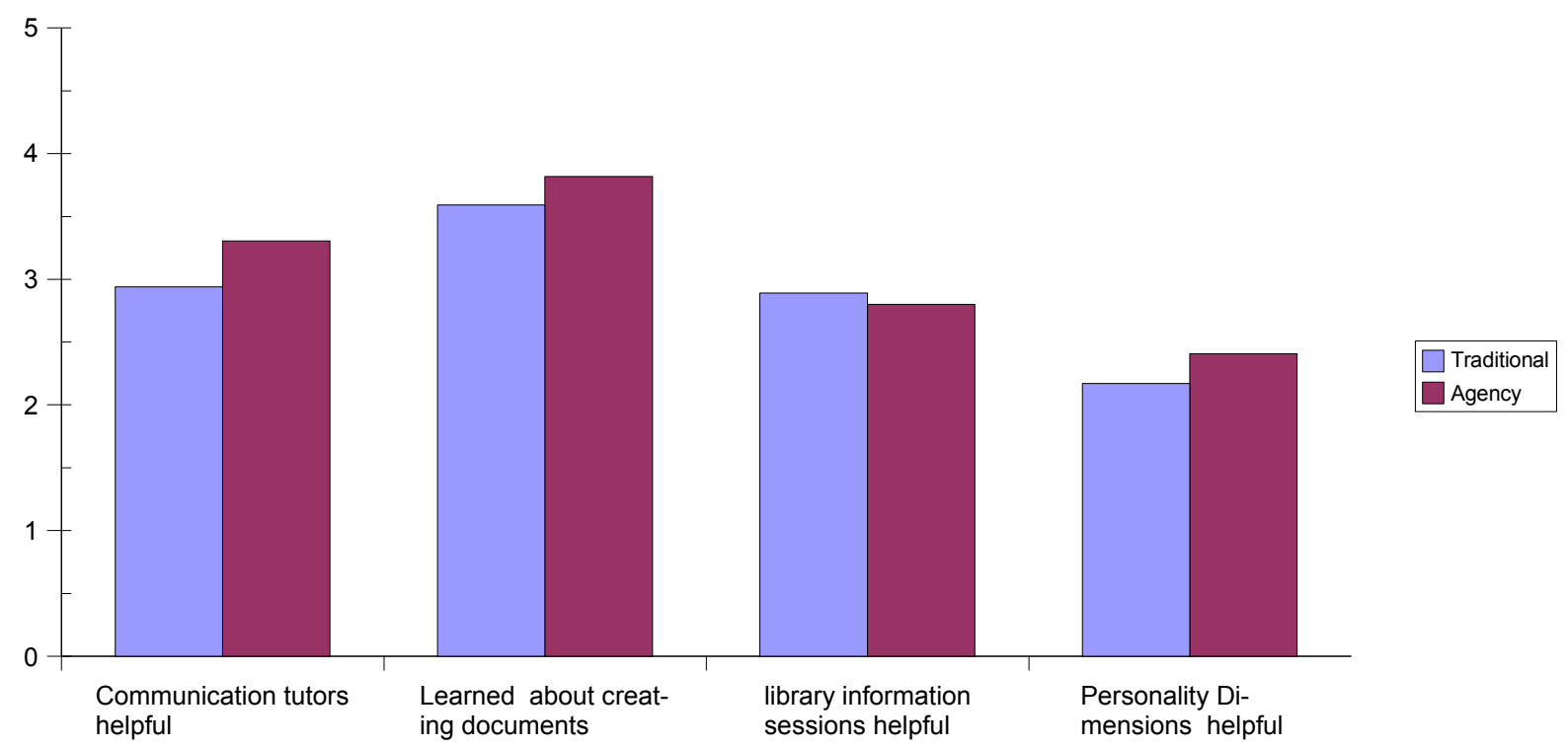

Figure 2: Student survey responses to questions about workshops

The most significant result of the survey, and one with the largest difference in students responses, is the significantly larger number of respondents on agency projects who indicated that their project encouraged the group to be creative. One of the fundamental objectives of the course is to expose students to truly open-ended projects, requiring creative problem solving, in contrast to more procedural laboratory experiments commonly seen in engineering for which the answers are known. Real-world CSL projects tend to be open ended, as clients

often have a problem for which they do not have a solution.
It is interesting to note that more students on agency projects felt they felt more comfortable doing oral presentations as a result of the project, and felt that the writing sessions were helpful. The link between the CSL projects and these attributes are not clear, but this will be examined in future years.

Compared to students working on traditional projects, a fewer students working on the CSL projects felt that their upper year project manager was a valuable source of information and guidance. This is somewhat expected, since the project managers on traditional projects are assigned based on their expertise in the 
area, while CSL project managers rarely have technical background relevant to the project.

Most students and project managers had very positive comments about the community service projects. The students were excited that their work would be used for a purpose, and contrasted their projects with the majority of students whose project would be discarded at the end of the term. Some of the students working on CSL projects commented that they spent more time on their projects than other APSC-100 students. This may be partially due to the more open-ended nature of the CSL projects, and to the students' motivation to complete projects when a community partner expects a deliverable.

The following are some survey comments from students in regards to the CSL projects:

Not a bad course, it was fun getting to be creative for credit and I loved that we were doing something meaningful.

The design project was good and I learned a lot. This is probably the most usefull course so far because it deals with real world applications.

My project with the landfill was very interesting. and it opened my eyes to the garbage problem that our cities are faceing.

Good course, I learned a lot about working in a team and about engineers in the community. I made some great friends, and felt like I was making a positive contribution to the community.

I had a very good experience with this course because I had an awesome group to work with. I liked that what we were doing was applicable to the real world and for the purpose of helping someone.

\section{Conclusions and next steps}

Overall, the introduction of CSL into the design projects was a positive step, and well received by students and community agencies. Feedback from students indicates that projects developed in collaboration with community groups are perceived as requiring more creativity, which is a step in the right direction.

In the coming years the CSL projects will be designed in more detail, ensuring that the projects naturally lend themselves to the development of professional skills, including design and information literacy. We would like to assess how the CSL projects contribute to student learning, complementing the surveys of student self-assessment. The effect of CSL on academic performance as measured by marks is mixed [6], though there appears to be a demonstrated benefit in terms of critical thinking and problem analysis. We are also currently working with specialists in engineering communications to asses the improvement in student writing skills in these projects.

\section{References}

[1] M. Thompson, W. Oakes, G. Bodner, "A Qualitative Investigation of a First-Year Engineering Service-Learning Program", Proceedings of the 2005 ASEE Annual Conference, 2005

[2] APSC-100 course webpage, http://appsci.queensu.ca/courses/APSC100/

[3] A. K. Topper, L. Clapham, "From Experiments to Experimentation; A New Philosophy for First Year Laboratories", Canadian Conference On Engineering Education, August 2001, Victoria, B.C.

[4] National and Community Service Act of 2000, retrieved March 14, 2007 from http://www.nationalservice.gov/pdf/cncs statute.pdf

[5] Community Service-Learning in Canada:A Scan of the Field (2006). Canadian Association for Community Service Learning, retrieved March 14, 2007 from http://www.communityservicelearning.ca/en/documen ts/ScanofCSLinCanada 000.pdf

[6] J. Eyler et al., "At a Glance: What We Know About the Effects of Service-Learning on College Students, Faculty, Institutions, and Communities, 1993-2000", Learn and Serve America National Service Learning Clearinghouse, retrieved March 9, 2007 from http://www.compact.org/resources/downloads/aag.pdf

[7] "The Engineer of 2020: Visions of Engineering in the new century", National Academy of Engineering, National Academies Press, Washington, D.C., 2004

[8] E. Coyle, et al. "EPICS: Engineering Projects in Community Service", International Journal of Engineering Education, 21(1), 2005, pp. 139-150 
[9] Community Service Learning in Canada, Canadian Association for Community Service-Learning, http://www.communityservicelearning.ca/en/partnersh ips.cfm, accessed June 15, 2007

[10] "Engineers Without Borders - Curriculum Enhancement", Engineers Without Borders, http://www.ewb.ca/en/whatwedo/canada/projects/curri culum.html, accessed June 15, 2007

[11] W. Cluett, "Teaching Design, Synthesis and Communication to First Year Engineering Students at the University of Toronto", ASEE Annual General Conference, 2004

[12] S. McCahan, D. Bagley, P. Weiss, K. Woodhouse, W. Cluett, "Engineering Education for the $21^{\text {st }}$ century: Changing curriculum at the University of Toronto", Engineering Dimensions, July-August 2003, pp. 37-39

[13] "Sample Projects - Engineering Strategies \& Practice", University of Toronto, http://www.ecf.utoronto.ca/ apsesp/csamples.htm, accessed June 15, 2007 